\title{
Ivan Nikiforovich Artsybasov
}

1927-1997

We were greatly saddened to learn of the death of Professor Ivan Nikiforovich Artsybasov, doctor of laws, member of the Russian Academy of Military Science and recipient of official Russian Federation honours for his contribution to international law.

Professor Artsybasov's renown as a leading expert in the law of armed conflict reached far beyond the boundaries of his home country. He is the author of over fifty works, published both in Russia and abroad, on international legal regulation of relations during armed conflict. His writings in this field made a significant impact on the development of Russian doctrine on the law of armed conflict and related legislative practice.

Professor Artsybasov devoted more than thirty years of his life to fruitful academic activity and research at Moscow's Military University, where he occupied the chair of theory and history of the State and of international law. It was also there that in 1981 he submitted and successfully defended his doctoral dissertation on the "International legal problems of armed conflict regulation". In 1989 he published, together with the author of these lines, a book entitled "Armed conflicts: Law, Policy, Diplomacy".

His academic and pedagogical work and participation in numerous seminars and conferences were largely instrumental in improving the teaching of the law of war in military educational institutions of the Russian Federation, and in making the laws and customs of war better known by the troops.

One could hardly overstate the importance of Professor Artsybasov's contribution to the promotion of international humanitarian law. For his active participation in spreading knowledge of the rules of international 
humanitarian law applicable in armed conflict he was awarded the N.I. Pirogov medal by the Alliance of the Red Cross and Red Crescent Societies of the USSR.

Ivan Nikiforovich Artsybasov was a wonderful person and a gifted teacher and scholar. He was a man whom we will not forget.

Sergei Alexeyevich Yegorov Professor, Diplomatic Academy Ministry of Foreign Affairs, Moscow 